\title{
Should the Culture Be Engaged? Modern Islamic Literature and Its Religious and Political Engagement
}

\author{
M. Kubarek
}

When literature began to develop in the Arab world, the utilitarian and aesthetic functions of a literary work were seen as mutually complementary. It was not until the Arab renaissance (Al-Nahda) in the $19^{\text {th }}$ century that, under the influence of European ideas, some changes occurred in the perception of the role of a literary work even though they were limited to a small group of experimenters. Regardless of their ideological or political affiliation, prose writers, poets and playwrights treated their creative work as a continuation of the traditional mission. The 1980s saw a rise of fundamentalism and development of a new kind of literature, described as "Islamic literature" (al-adab al-islami). Its goal was to oppose the moral degradation promoted by secular literature imitating Western models on the one hand, and on the other, to shape attitudes and moral standards consistent with the principles of Islam. The article describes the cultural and socio-political context of the development of this movement, and analyses how the role and form of a literary work has been perceived and defined by theorists of Islamic literature as well as Arab authors and readers.

Index Terms-Arab world, Arabic literature, Arabic culture, Islamic literature.

\section{INTRODUCTION}

Taking as the point of departure the following observation made by Andrzej Werner about the links between literature and authority: "As a historian of literature, I look with certain distrust at such general concepts, fixed neither temporally nor geographically" [1] one should begin the examination of the involvement of Islamic literature with defining the time and geographical frame of this phenomenon and describing the factors that influenced its formation.

Unengaged literature is a marginal phenomenon in the Arab world because, according to the tradition deeply rooted in Arab culture and originating from the times of the tribal poets, the word has always had a power to make things happen and a task to fulfil.

The origins of Arabic literature date back to pre- Islamic times, when poetry developed in the Bedouin communities of the Arabian Peninsula as early as the $5^{\text {th }}-6^{\text {th }}$ AD. The sophisticated, at first orally transmitted, long poems known as qasid have basically survived in an almost unchanged form until the present. The continuity does not apply to the subject matter but primarily to the language and form, subordinated to strict metric rules [2].

Manuscript received February 9, 2016; revised April 1, 2016.

The author is with the Nicolas Copernicus University in Torun, Department of Arabic Language and Culture, Poland (e-mail: magdakubarek@poczta.onet.pl).
A Bedouin poet, as an author of panegyrics or satires, enjoyed huge respect and performed the role not only of a speaker for his tribe but also of a shaman:

The high prestige of the poet in a tribe resulted from the role played in the tribal community by language, particularly literary, poetic and, consequently, mythical language. Linguistic utterances were equally significant as actions. Such a far-reaching performative function of a linguistic utterance was recognised both by the speakers and the recipients. It is no wonder that a satire was feared as much as an armed attack. The poet was an actual hero, a real warrior whose status was even greater because he represented the entire tribe [3].

This great appreciation of poetry and respect for those who can use language as an efficient weapon remain a feature of Arab society today. The faith in the magical and causative function of language has been manifested most fully in the holy book of Islam - the Quran. The new religion that was revealed in the $7^{\text {th }}$ century to Muhammad, who originated from the Mecca-based Quraysh tribe, reinforced the prestige of Arabic. Besides poetry, the Quran, with its collection of divine revelations, constitutes not only the source text of Islam but also the largest monument of the Arabic language and an unmatched model of belles-lettres that has inspired the successive generations of writers.

In the subsequent centuries, the Arabs and the peoples they conquered jointly built the legacy of Arabic-Islamic literature, contributing to its evolution and blossoming. Under the reign of the Abbasids (750-1258), a new type of writing developed, namely $a d a b$, which means upbringing, instruction. To an educated inhabitant of the Abbasid Caliphate, adab works constituted indispensable compendia of various fields of knowledge: philology, rhetoric, religion, philosophy, history or geography. With time, the term $a d a b$ acquired a broader meaning and began to denote the entirety of literary works.

The utilitarian function of a work of literature, following from the conviction prevalent among the Arabs about the causative function of language, also prevailed in the Arab renaissance in the $19^{\text {th }}$ century when the pioneers of new literature adapted Western genres (short story, novel, drama) and took upon themselves the task of educating the society in a modernist spirit, shaping national identity and rallying people to fight against the colonizers. Similar ideas motivated authors who gave the traditional form of classical poems to topical subjects and ideological involvement.

In the second half of the $20^{\text {th }}$ century, after the formation of modern State organisms, literature served as a propaganda tool for the existing regimes or as the voice of the opposition. The calls of the French existentialists for the moral, social 
and political engagement of writers in the problems of their times (and these problems were numerous) also reached the Arab world. Thus, writers have been taking a specific stance on the troubles in the Arab world, from Algeria's war of independence to the Palestinian problem or the Persian Gulf crisis. In one form or another, the successive bloody armed conflicts and struggles against the ruling regimes have been reflected in the works of new generations. However, the writers have also got involved in social causes, defending the excluded, the poor, women or children.

\section{DAWAH}

The defeat of the Arab armies in the war against Israel in 1967 was followed by an ideological crisis that, in later years, resulted in the rise of fundamentalist sentiments, also in the intellectual circles. Religion marginalised the old socialist or pan-Arabic ideas and again became an important element of social discourse and the new Arab identity. The main tenets of Islamic fundamentalism, such as the necessity to defend values against Western economic, political and ideological interference, were now voiced more and more loudly. The departure of modern societies from traditional values and the imitation of the West were viewed as the reasons for the defeats and backwardness of the Arab world. A need to develop suitable tools to propagate new ideas also emerged. Taking into account the traditionally involved role of the word in Arabic culture, it does not come as a surprise that many intellectuals and authors turned to literature.

The popularisation of religiously involved literature is linked with the activity of the Muslim Brotherhood, an organisation founded by Hasan al-Banna in Egypt in 1928 [4] [5]. Al-Banna reformulated the traditional interpretation of mission (dawah):

(...) Al-Banna called for the development of education but this development was aimed at the dissemination and renewal of the rules of Islam. (...) He also reformulated the dawah ("issuing a summons", "making an invitation") (...). With Al-Banna's activity (...), the term began to denote active missionary work based on religious propaganda and conversion to Islam. According to this programme, Al-Banna was encouraging Muslim Brotherhood members to take an active part in public debates, held in mosques, schools and the mass media, about the growing role of Islam in the political and social life of the believers [6].

The subsequent leaders of this movement, with its main ideologue Sayyid Qutb (1906-1966) and his brother Muhammad (b. 1919), began propagating the idea of using art, including literature, as an efficient tool of missionary work [7] [8]. However, it was not until the 1980s that literature described as Islamic (al-adab al-islami) became popular. At present, this term encompasses poetry, prose and drama. However, readers are mostly interested in prose represented by the novel (riwaya) and short story (qissa), i.e. genres adopted from Western Europe in the $19^{\text {th }}$ century.

The propagation of new literature in the Arab and Muslim world was furthered by the activity of the International League of Islamic Literature (Rabitat al-Adab al-Islami
al-Alamiyah), an organisation founded in 1984 by a Hindu, Alim Abu al-Hasan Nadwi (1914-1999), who was also its first president. In the 1940s and 1950s, both Sayyid Qutb and Nadwi advocated the development of Islamic literature [9]. After Nadwi passed away in 1999, the headquarters of the organisation, until then located in Lucknow, India, were moved to the capital of Saudi Arabia. Abd al-Quddus Abu Salih, a literary scholar from Syria and one of the founders of the League, is its current president.

On its website (http://adabislami.org/intro.html) the League clearly draws on the concept of the dawah and the role of literature in the life of a pious Muslim as advocated by Hasan al-Banna and Sayyid Qutb:

It was probably the duty to invoke (dawah) God Almighty through the authentic and engaged word, to strive to strengthen Islamic literature and counteract the dissemination of false literature in the Arab and Muslim world, that led a small group of Muslim writers to establish the League. When the League closes its ranks, it will give a brotherly helping hand to each of them, it will strengthen their voice, it will assist in the duty of building the foundations of Islamic literature, in the critique of literary schools around the world and in developing modern methods of literary criticism as well as clarifying what is positive and what is negative about them.

\section{Al-ADAB Al-ISLAMI: DEFINITION AND CRITERIA}

The range of impact of Islamic literature, as a form and tool of the mission targeting primarily Muslims who have changed their lifestyle under the influence of Western culture, has been growing. Since a rising number of writers were using texts to manifest their commitment to the cause, a need arose to formulate a definition of al-adab al-islami as well as the criteria according to which a given work can be assigned to this kind of literature.

Muhammad Qutb, already mentioned above, and Najib al-Kilani were the first to undertake this difficult task. For Qutb, Islamic literature is:

A beautiful way of expressing the world, life, man. It is an art where beauty meets truth in a perfect manner. And beauty is the truth of existence while the truth is the apex of beauty. That is why they come together in a story where all the truths of existence meet [10].

Najib al-Kilani (1931-1995) was the first to use the term "Islamic character" (al-islamiyah) in the context of literature in his dissertation Al-Islamiyah wa-al-Mazahib al-Adabiyah (The Islamic Character and Literary Schools). He is described as the pioneer or father of Islamic literature [11]. Al-Kilani defines Islamic literature as a responsibility and obligation that flows from the heart and convictions of a believer and is based on the Divine Book revealed in the clear language of the Arabs" [12].

The concepts of Qutb and Al-Kilani were developed by Imad ad-Din Khalil (b. 1939), an outstanding Iraqi intellectual, author of studies on contemporary Muslim 
thought. In Madkhal ila Nazariyat al-Adab al-Islami (Introduction to the Theory of Islamic Literature), Khalil defines the functions that al-adab al-islami should fulfil. The most important and superior is the doctrinal function, followed by the political, social, psychological, historical, methodological and educational function. Thus, Islamic literature is an engaged literature (al-adab al-multazim or al-adab al-masul) and contradicts the concept of art for art's sake.

For Khalil, Islamic literature is not only determined by the Muslim perspective and philosophy but also by aesthetics referring to Quranic models. Khalil thus stresses the existence of the second, equally important criterion that defines Islamic literature.

Many writers believed, and still believe, that the subject is the only criterion for the Islamic character of literature. This is not the right path, however (...). Islamic literature is not supposed to be simple "how-to literature." It must be belles-lettres indeed. To Khalil, this principle follows from the Quran [13].

Khalil thus tries to challenge the view that the engagement of literature has a negative impact on its aesthetic value. To a Muslim, such a view seems to contradict itself because the Quran is an unsurpassed model of literature in Arabic.

The combination of beauty and truth is what makes Islamic literature different from other kinds of literature. In accordance with Khalil's assertions, al-adab al-islami is created through divine inspiration while other literary works draw from human experience, and that is why Islamic literature is a separate form and does not lend itself to classic categorisation. Therefore, the terminology adopted in Western literary theory is not an adequate tool for describing literature created through divine inspiration. It cannot be described as a trend or genre. Its engagement is neither linked with Marxist or socialist ideology, unlike most realist works, nor with existentialism which most works focussed on the experiences of an individual refer to. Nor does it propagate capitalist ideas such as individual freedom and accumulation of goods. Islamic literature is based on harmony between spiritual and material values [14].

The final determinant of Islamic literature is its humanism even though this criterion is disputed by some theoreticians and practitioners of this genre [15]. Those who propagate the view that the essence (djauhar) of the Islamic perspective can also be found in works written by non-Muslim writers include Muhammad Qutb who gives examples of such works in Madkhal ila al-Fann al-Islami. A similar view on this issue is shared by Imad ad-Din Khalil who stresses the significance of the universality of this religion and its humanistic values [16].

Regardless of the disputes among theorists, the term Islamic literature is now widely used and more and more works are described with this term by critics, publishers, readers and the authors themselves. The activity of the League has contributed a lot to the increased popularity of al-adab al-islami in the Arab world and beyond it. On its official
(http://www.adabislami.org/English/whatis.html), the League presents the following definition of Islamic literature:

Islamic literature is the objective artistic expression of man, life and universe from an Islamic perspective" (at-tabir al-fanni al-hadif an al-insan wa-al-hayat wa-al-kaun wufq at-tasawwur al-islami).

The reflections above indicate that the criteria developed by theorists of Islamic literature remain imprecise. On the one hand, al-adab al-islami encompasses all works drawing on universal spiritual values and not contradicting the Islamic doctrine, and they can be created by non-Muslims. On the other hand, this term is applied to works propagating the ideas of Islamic fundamentalism. Due to this lack of precision, al-adab al-islami encompasses very different works, including those whose authors do not identify with this movement.

Islamic literature is also created outside the borders of the Muslim world. This phenomenon has the greatest reach in regions where Muslims account for a considerable percentage of the population but it can also be observed in countries with a very small number of Muslims, for example in Poland. The biggest number of works recognised as Islamic literature are written in English. Owing to its educational character, it is often created by young or beginning writers and is intended for juvenile audiences. The US-based Islamic Writers Alliance developed its own definition of Islamic fiction (http://www.islamicwritersalliance.net/index.html):

Islamic Fiction refers to creative, imaginative, non-preachy fiction books written by Muslims and marketed primarily to Muslims. Islamic Fiction may be marketed to mainstream markets, too. The content of these books may incorporate some religious content and themes, and may include non-fictionalized historical or factual Islamic content with or without direct reference to the Qur'an or the Sunnah of the Prophet (pbuh). The stories may also include modern, real life situations and moral dilemmas. Islamic fiction authors intend for readers to learn something positive about Islam when they read Islamic fiction stories. Islamic Fiction does not include Harmful Content: vulgar language, sexually explicit content, un-Islamic practices that are not identified as un-Islamic, or content that portrays Islam in a negative way.

The authors of the portal also published a list of books that, in their opinion, meet the above criteria even though the authors of these books do not necessarily associate their works with Islamic literature.

The works of Arab authors writing in European languages constitute a peculiar type of Islamic literature that straddles the boundary between the two worlds. These works cannot be classified in an unequivocal way. Books by a Sudanese writer Leila Aboulela, winner of many literary awards, can serve as an example in this respect. Her novels such as The Translator, Minaret or Lyrics Alley, were written in English and published in New York [17] - ]19]. 


\section{ENAGAGMENT AND A WORK OF LITERATURE}

Thanks to its growing popularity, over the last three decades, al-adab al-islami has become the subject of research and academic dissertations and critical studies in the Arab and Muslim world [20]. As the Polish Arabist and Islamic studies scholar Marek M. Dziekan observes, there are very few Western studies on Islamic literature. Johann Ch. Bürgel, one of the few Orientalists in the West to recognise this phenomenon, offers the following definition of Islamic literature:

The name adab islami itself, by analogy, resembles the name of medieval medicine known as Islamic medicine or prophetic medicine (tibb islami, tibb nabawi). This distinction was aimed at replacing what the fundamentalists at that time regarded as a pagan creation, i.e. Galen's medicine, inherited from the Greeks. The process seems logical and consistent with the concept that the history of Islamic culture should be perceived as a never-ending history of Islamisation of cultural phenomena whose pagan power should be subordinated to the Divine Omnipotence. Western and pro-Western literature in [Muslim] countries is regarded by these authors as morally corrupt. That is why the time has come to oppose it with Islamic values [21].

Literature linked with ideology — whether in a democratic or undemocratic system - is usually regarded by European researchers as dangerous and undesirable because such literature loses its value as it becomes an instrument of propaganda.

The author's engagement, which attests to the truthfulness of Islamic literature according to its theorists, is regarded in a totally different way by European critics with their memory of the subordination of art to $20^{\text {th }}$-century totalitarian ideologies, i.e. Nazism and Communism:

The consequences of ideological subordination of literature are self-evident. It is subordinated to "higher causes" and, consequently, it is deprived of the right to doubt, which is a guarantee of the author's honesty (...). Hence the symbiosis of literature and ideology can only result in a lie: psychological lie, historical lie, political lie, ethical lie (...) [22]

On the other hand, European researchers claim that, regardless of the variety of functions that literature can perform, every text is engaged in some way or another, or it is axiologically marked. Therefore, from the perspective of the myth-making or exposing function, literature can be classified as literature "for" and literature "against."

To use these terms, Islamic literature can be described as literature "both for and against" as it combines both functions On the one hand, it promotes the desirable models of behaviour and attitudes while, on the other hand, it opposes the cultural, ideological and economic influences of the West and challenges the ruling regimes that are regarded as representatives of Western interests.

The discourse about whether good literature can be created in a democratic system seems to be justified and appropriate because it is conducted by researchers living in a democratic system. It is pointless, however, in the Arab world that has not experienced and does not desire democracy in the Western meaning of the term. The different perspective manifested in the views of many Arab intellectuals and writers, not only those linked with fundamentalism, is aptly summarised by Jonathan Swift's stance cited by Paweł Kłoczowski:

I like tolerance when I am a strongman among weaklings, a giant among lilliputians: tolerance then is a sign of my strength. It is a different matter when I am a lilliputian among giants. I do not like tolerance when I can be trampled upon, beaten and crushed at any time (...), when every move of the giant's finger dictates how I should behave and my deepest convictions are the butt of jokes, an object of games. I do not like the negative freedom from coercion when it involves a risk of death or disability [23].

Returning to the reflections of Andrzej Werner, quoted at the beginning of this article, we have to accept that the reception of a literary work is different in the West and in the East. In democratic societies, as a result of political and civilisational changes, it is believed that the voice of the writer is no longer listened to and respected. What is more, the postmodernist evolution has resulted in the limitation of the social functions of literature whose supremacy in the world of culture has been taken over by the mass media [24].

In the Arab countries, prose writers, poets and playwrights still have important tasks to perform beyond the sphere of aesthetics. Furthermore, they often encounter various forms of persecution or discrimination because of their involvement. In the case of writers from the Muslim Brotherhood circles, it is difficult to separate their political activity from their writing. Many of them, however, were arrested or forced to emigrate. Najib al-Kilani served time in prison twice in his youth. As a result of the recent political changes in Egypt, most works classified as Islamic literature are withdrawn from bookshops and selling them is prohibited.

\section{CONCLUSION}

The Arabs have always been proud of their language, believing that "there was some extraordinary power in it." Therefore, both poetry and the works of classical and neoclassical prose were characterised by great attention to form as well as methodical and sophisticated language. On the other hand, since the utilitarian function of a literary work is deeply rooted in Arabic culture, it is not believed that the engagement of literature has a negative impact on its aesthetic value: both the authors and readers consider these functions to be mutually complementary.

\section{REFERENCES}

[1] A. Werner, "Jak literatura jak władza," in Literatura $i$ Władza, B. Wojnowska, Ed. Warszawa: Wydawnictwo Instytutu Badań Literackich PAN, 1996, p. 259.

[2] W. Walther, Historia Literatury Arabskiej, Warszawa: Wydawnictwo Naukowe PWN, 2008, pp. 41-42.

[3] J. Danecki, Poezja Arabska - Wiek VI-XIII, Wrocław: Ossolineum, 1997, p. 16 
[4] A. Mrozek-Dumanowska, Islam i Jego Odnowa, Warszawa: Wydawnictwo Naukowe Askon, 2001, p. 62.

[5] W. Grabowski, Fundamentalizm Muzutmański na Bliskim Wschodzie, Gdańsk: Wydawnictwo Uniwersytetu Gdańskiego, 2013, pp. 32-38.

[6] A. Mrozek-Dumanowska, Islam i Jego Odnowa, Warszawa: Wydawnictwo Naukowe Askon, 2001, p. 60.

[7] M. M. Dziekan, "Die islamische Literathurteorie und-Kritik von Imād ad-Dīn Halīl. Ein Vergleichendes Studium," Rocznik Orientalistyczny, vol. 62 , no. 2, pp. 15-25, 2009.

[8] M. Kubarek, "Współczesna literatura muzułmańska w krajach arabskich," Litteraria Copernicana: Arabia. Stałe $i$ zmienne w literaturze arabskiej," no. 13, pp. 39-53, 2014.

[9] M. M. Dziekan, "Die islamische literathurteorie und-Kritik von Imād ad-Dīn halîl. ein vergleichendes studium," Rocznik Orientalistyczny, vol. 62, no. 2, p. 16, 2009.

[10] M. Qutb, Manhaj Al-Fann Al-Islami, Al-Qahira: Dar Al-Shuruq, 1960, p. 6 .

[11] M. H. Barighish. Dirasat fi al-Qissa al-Islamiyya al-Mu'sira, Beirut: Mu'assasat al-Risala, 1994, pp. 35-38.

[12] M. Kubarek, "Muzułmańska perspektywa w twórczości Nağība al-Kaylānīego," Orient w literaturze-literatura w Oriencie. Spotkania, A. Bednarczyk, 2014, pp. 167-179.

[13] M. M. Dziekan, "Die islamische literathurteorie und -kritik von Imād ad-dīn halīl. ein vergleichendes studium," Rocznik Orientalistyczny, vol. 62 , no. 2 , pp. 11, 2009.

[14] I. ad-Din Khalil, Madkhal ila Nazariyat al-Adab al-Islami, Dimashq-Bayrut: Dar Ibn Kathir, 2007, pp. 171-181.

[15] M. Kubarek, "Modern Islamic literature in the Arab world," presented at the $27^{\text {th }}$ Congress of the Union Europeenne des Arabisants et Islamisants, Helsinki, Finland, 2-6 Jun. 2014.

[16] I. ad-Din Khalil, Madkhal ila Nazariyat al-Adab al-Islami, Dimashq-Bayrut: Dar Ibn Kathir, 2007, pp. 211-213.

[17] L Aboulela, The Translator, NY: Grove Press, Black Cat, 1999.

[18] L Aboulela, Minaret, NY: Grove Press, Black Cat, 2005.

[19] L. Aboulela, Lyrics Alley, NY: Grove Press, 2011.

[20] S. Hafez. (September-October 2000). The novel, politics and Islam. [Online]. Available: www.newleftreview.org/?view $=2274$
[21] J. C. B Brgel, "Der Islam im spiegel zeitgenössischer literatur islamischer Völker," in Islam in der Gegenwart, W. Ende, U. Steinbach, G. Kr ${ }^{\smile}$ ger, Eds. M ${ }^{\smile}$ nchen: C.H. Beck Verlag, 2005, p. 823.

[22] J. J. Szczepański, "Inżynieria dusz?," in Literatura I Demokracja. Bezpieczne I Niebezpieczne Zwiazki, M. Gumkowski, Ed. Warszawa: Wydawnictwo Instytutu Badań Literackich PAN, 1995. p. 63.

[23] P. Kłoczowski, "Czy tolerancja niszczy sztukę." in Literatura i władza, B. Wojnowska, Ed. Warszawa: Wydawnictwo Instytutu Badań Literackich PAN, 1996, pp. 103-104.

[24] A. Werner, "Jak literatura jak władza," in Literatura $i$ władza, B. Wojnowska, Ed. Warszawa: Wydawnictwo Instytutu Badań Literackich PAN, 1996, p. 259

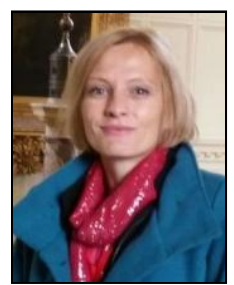

M. Kubarek was born 1975 in Krynica (Poland). She graduated MA studies at the Jagiellonian University in Cracow, in 2001, Institute of Oriental Philology, Arabic studies, a PH.D studies in 2007, at the University of Warsaw, Faculty of Oriental Studies. Ph.D. Thesis (The Death Motif in the Works of Contemporary Arab Women Poets). She is a researcher in the field of contemporary Arabic literature and intercultural interferences.

Since 2009 she teaches Arabic language in the center for Eastern Languages at the University of Warsaw, and since 2012 also works as assistant Professor in the Department of Arabic Language and Culture at Nicolas Copernicus University in Torun. The list of her accomplishments includes over 20 publications. Among them one monograph: Motyw śmierci w twórczości współczesnych poetek arabskich (The Death Motif in the Works of Contemporary Arab Women Poets, 2009). She has also published translations of Arabic literature. Abd ar-Rahman Munif, Miasta soli, (Cities of Salt, 2010), and Khalil Gibran, Połamane skrzydła, (Broken Wings, 2012).

Dr. Kubarek is a board member of the Polish Orient Society, a member of Union Européenne des Arabisants et Islamisants She also organizes annual conferences on orientalism and Oriental literatures taking place at Nicolas Copernicus University in Torun. 